Gut, 1985, 26, 1338-1348

\title{
Endoscopic laser treatment of vascular anomalies of the upper gastrointestinal tract
}

\author{
S G BOWN, C P SWAIN, D W STOREY, C COLLINS, K MATTHEWSON, \\ P R SALMON, AND C G CLARK
}

\section{From the Departments of Gastroenterology, Surgery and Pathology, University College Hospital, London}

SUMMARY Vascular anomalies of the gastrointestinal tract are an important source of both acute and chronic blood loss. They present difficult management problems as they are often multiple, involving more than one part of the gastrointestinal tract, and may give rise to bleeds of increasing frequency and severity over a period of many years. We present the results of endoscopic argon and Nd YAG laser treatment of 18 patients with documented recurrent, severe haemorrhage from vascular lesions of the upper gastrointestinal tract with follow up of up to five years. Four patients with hereditary haemorrhagic telangiectasia, five with single angiodysplasias and three with multiple angiodysplasias have had their transfusion requirements reduced to minimal levels after one or more courses of laser treatment. Two of these have required no blood for over two years despite previous total requirements of 52 and 129 units of blood. Four patients were submitted to surgery (two in whom the laser failed to control haemorrhage and two who did not have immediate access to laser therapy at the time of severe bleed). Two of these, however, bled again soon afterwards. Two patients are still undergoing courses of laser therapy although have already shown reductions in transfusion requirements. Both lasers were effective. The Nd YAG laser appears to produce better long term results as its greater penetration makes it possible to ablate the main areas of vascular ectasia in the submucosa, although it does have a slightly higher risk of causing haemorrhage in the first few days after treatment.

Vascular anomalies of the upper and lower gastrointestinal tract can cause acute and chronic blood loss and although relatively rare, are being recognised with increasing frequency both at endoscopy and angiography. They may be responsible for up to $3 \%$ of upper gastrointestinal bleeds ${ }^{1}$ and as many as $35 \%$ of severe acute lower gastrointestinal bleeds. ${ }^{2}$ A range of non-neoplastic vascular anomalies occur in the gastrointestinal tract. The most specific lesions are those of hereditary haemorrhagic telangiectasia or Osler-Weber-Rendu Syndrome. About $13 \%$ of patients with haemorrhagic telangiectasia have significant gastrointestinal haemorrhage. ${ }^{3}$ Single or multiple lesions without the associated features of haemorrhagic telangiectasia are more likely to be degenerative in nature and are referred to in this report as angiodysplasias. ${ }^{4}$ These have been associated with valvular heart disease (particu-

Address for correspondence: Dr S G Bown, Department of Surgery, School of Medicine, University College London, The Rayne Institute, University Street. London WC1E 6JJ.

Received for publication 31 January 1985 larly aortic stenosis), chronic haemodialysis, connective tissue disease and previous radiotherapy and their incidence increases with advancing age. ${ }^{56}$ Those in the caecum have been thought to be produced by chronic, intermittent low-grade obstruction of submucosal veins. ${ }^{4}$

In both haemorrhagic telangiectasia and angiodysplasia, the essential features are fragile leashes of thin walled blood vessels in the submucosa which may break through the mucosa (perhaps by minor local trauma or increased venous pressure) and cause significant blood loss into the lumen of the gut. ${ }^{478}$

The treatment modalities that have been tried include surgery, ${ }^{39}$ oestrogen therapy ${ }^{10}$ and various endoscopic techniques. The endoscopic methods of treatment that have been reported to be of value include diathermy, ${ }^{511}$ sclerotherapy ${ }^{12}$ and lasers. ${ }^{13-16}$ Few reports, however, have discussed the precise aims of endoscopic therapy or documented the details of blood loss before and after treatment in individual patients. 
In this report, we analyse 18 cases referred for laser treatment for whom we have precise details of recurrent haemorrhage of varying severity prior to referral and follow up for periods up to five years.

\section{Methods}

\section{PATIENTS}

All patients were referred to University College Hospital for laser treatment with a firm or provisional diagnosis of haemorrhage from vascular lesions of the upper gastrointestinal tract. The diagnosis was confirmed at endoscopy carried out under sedation with diazepam and performed with care to minimise local trauma from the instrument (particularly from suction artefacts). Gastric secretions and any old or fresh blood were cleared from suspicious areas by gentle washing. A positive diagnosis was based on the identification of one or more bright red lesions on the mucosa (occasionally associated with small areas of superficial ulceration). These were raised (umbilicated), flat or depressed, but all lesions in any one patient were similar. Lesions seen to bleed spontaneously or which oozed on gentle washing or on treatment were thought most likely to be sites of significant blood loss. They varied in size from $1 \mathrm{~cm}$ diameter to less than $1 \mathrm{~mm}$ across, the latter only being distinguished from innocent red spots by the observation of bleeding. All but one had sharply defined margins and most were roughly oval in shape. (It should be noted that occasional large raised vascular lesions can be cavernous and deep and are not suitable for laser therapy). Patients with typical mucocutaneous lesions and a positive family history were considered as haemorrhagic telangiectasia (although one patient (case 7) without a family history was included as she had typical mucocutaneous lesions and multiple arteriovenous malformations, particularly in the liver and pancreas). ${ }^{3}$ Patients without these features were considered as angiodysplasias. All were given blood transfusions and iron supplements as required to maintain an adequate haemoglobin.

Initially, in 1979, only an argon ion laser was available (Model 770, Spectra Physics Ltd, St Albans). This was used at a power of 5-6 w with pulses of 1-3 seconds duration to ablate the mucosal lesion as seen endoscopically - that is, to blanch or destroy the red areas of vascular ectasia. This usually created a shallow ulcer and care was taken to limit the total energy deposited on any one spot to below $50 \mathrm{~J}$ (the safe limit established in animal experiments to avoid perforation). ${ }^{17}$ Some oozing was usually seen during treatment but this always ceased spontaneously. After laser treatment, full doses of cimetidine or ranitidine were prescribed for one month to hasten healing of the iatrogenic ulcers.

In 1981, a Nd YAG laser became available (Fiberlase 100, Barr \& Stroud Ltd, Glasgow) and since this time, all endoscopic treatment for this kind of lesion has been carried out with this instrument. As with the argon laser, the total energy on any one spot in one treatment session was limited to the safe limit established in animal experiments $\left(600 \mathrm{~J}\right.$ for this laser) ${ }^{18}$ using shots of $60-70 \mathrm{w}$ for 0.5 seconds. The immediate visual effect was, however, often different as the first change was blanching, to be followed a few days later by superficial ulceration rather than the immediate loss of superficial cells often seen with the argon laser. Both lasers caused superficial charring if fired at fresh blood. With both lasers, if the safe limit of energy dissipation was reached on any lesion without adequate visual effect, treatment on that spot was stopped, to be continued after a time interval of at least two weeks when the treated area would have had sufficient opportunity to heal to make further treatment safe. In all cases of haemorrhagic telangiectasia, there were too many lesions to treat in one session, but endoscopy could be repeated every few days, as different lesions were treated on each occasion. All patients had repeated endoscopies until it was judged that the vascular anomalies as visualised endoscopically had been ablated. If blood loss could not be adequately controlled endoscopically, surgery was carried out to resect the area containing the most significant lesions. Long term follow up was carried out at the referring hospitals and the patient seen again by us if further bleeding occurred. Blood transfusion requirements were documented as precisely as possible from the first evidence of gastrointestinal blood loss to the present time.

\section{Results}

Eighteen patients have been treated, eight with hereditary haemorrhagic telangiectasia and 10 with angiodysplasia (single and multiple lesions). All had required blood transfusion for acute blood loss before referral and eight had developed major problems in cross matching in view of the large numbers of transfusions they had received. Five had required previous surgical intervention for gastrointestinal blood loss. Two had segmental jejunal resections, one had a vagotomy and pyloroplasty and one a hemicolectomy. The fifth had a partial gastrectomy, a hemicolectomy and a segmental jejunal resection. Of all these seven procedures, only one of the jejunal resections and the partial gastrectomy had any definite benefit on reducing the blood loss. One patient had had previous successful embolisation of an arteriovenous malformation of 
the pancreas. Five patients also had lesions of the mitral or aortic valves and one was on chronic haemodialysis.

Details of the patients are shown in Table 1 and the results of treatment in Tables 2 and 3 . The pattern of blood loss in the two groups was different. The patients with haemorrhagic telangiectasia had longer histories of blood loss with less severe acute episodes, although all had increasing loss in the period leading up to their referral. To provide a comparison between patients in this group, the pretreatment requirements in Table 2 are given as the average monthly requirements for the three month periods up to and including initial or subsequent courses of treatment. Most of the patients with angiodysplasia had shorter histories (less than a year) of recurrent episodes of bleeding leading to their referral to us. The duration of this period varied from one to 24 months and the pretreatment transfusion column in Table 3 shows the average monthly requirements during this period. In cases in which major haemorrhage recurred, the period leading up to the second referral is shown as a second line in the pretreatment column. Figure 1 shows the pattern of blood loss in relation to the therapeutic manoeuvres applied for three illustrative cases. The number of laser endoscopies required to complete courses of therapy is shown in Table 4. The large number of sessions required to complete the initial course of treatment for patients 1 and 2 (11 and nine endoscopies respectively) reflects both our caution with a new technique and the large number of lesions present in each of these ladies. The multiple sessions required to treat single large angiodysplasias reflect the need to limit the energy dissipated on one spot at one time. The results for each course of therapy are shown in Table 5 and the current situation for each patient in Table 6.

There were no perforations. The only complication that might be attributable to the laser treatment was exacerbation of the bleeding. Four cases of haemorrhagic telangiectasia (numbers 1, 2,
7 , and 8 ) required transfusion during their initial course of treatment. For three (cases 1,2, and 8) the quantity of blood needed diminished as the number of lesions treated increased, suggesting a steady response to therapy. Haemorrhage was only controlled for two months in case 1 and when it recurred, could not be adequately controlled by four further laser endoscopies, necessitating a partial gastrectomy. Case 7 required 12 units of blood in the week before referral. The bleeding came predominantly from a single lesion (only 1-2 $\mathrm{mm}$ in diameter) in the body of the stomach. This was stopped temporarily on six separate occasions over a period of two months (twice, arterial haemorrhage was arrested with the laser), but haemostasis never lasted more than a few days and eventually she underwent a sleeve resection of the main lesion, since when she has been well. Although the laser failed to control her blood loss, it probably did not exacerbate it, as the rate of transfusion required was highest in the week before her referral.

Three angiodysplasia cases bled during the course of treatment. Case 17 had three major bleeds of comparable severity (8-10 units of blood transfused), the first before referral, the second four days after his first treatment (both of which settled on conservative therapy) and the third, 13 days after his third treatment, at which time he was submitted to laparotomy, as no experienced laser endoscopist was available. Several lesions had received no laser treatment at the time of laparotomy and it was not possible to establish whether he had bled from treated or untreated lesions. In the other two (cases 14 and 18), haemorrhage seemed more likely to be directly related to therapy. These bleeds occurred a few hours and seven days after treatment, but settled spontaneously, only requiring 4 and 2 units of blood respectively. The most serious complication occurred in case 6 who bled three days after $\mathrm{Nd}$ YAG laser treatment of residual telangiectasia in the stomach at a routine follow up endoscopy. He was admitted from home to the referring hospital, where he required a laparotomy to oversew a

Table 1 Details of patients in study

\begin{tabular}{|c|c|c|c|c|}
\hline & \multirow[b]{2}{*}{$H H T$} & \multicolumn{3}{|c|}{ Angiodysplasia } \\
\hline & & Single & Multiple & Diffuse \\
\hline Patients (no) & 8 & 5 & 4 & 1 \\
\hline Sex & 5 F $3 \mathrm{M}$ & $3 \mathrm{~F} 2 \mathrm{M}$ & $3 \mathrm{~F} 1 \mathrm{M}$ & $1 \mathrm{~F}$ \\
\hline Age & $62(42-74)$ & $66(47-88)$ & $76(72-81)$ & 62 \\
\hline Period of GI bleeding & 13 yrs $(2-32$ yrs $)$ & $7 \mathrm{~m}(3-16 \mathrm{~m})$ & $9 \mathrm{~m}(1-24 \mathrm{~m})$ & $17 \mathrm{~m}$ \\
\hline Total blood transfused (units of $540 \mathrm{ml}$ ) & $130(19-300)$ & $45(16-107)$ & $57(4-177)$ & 87 \\
\hline
\end{tabular}

HHT=haemorrhagic telangiectasia. 
Table 2 Results for patients with hereditary haemorrhagic telangiectasia (HHT). Blood transfusion requirements are given in units of $540 \mathrm{ml}$

\begin{tabular}{|c|c|c|c|c|c|}
\hline \multirow[b]{2}{*}{ Case no } & \multirow{2}{*}{$\begin{array}{l}\text { Average blood } \\
\text { reauirements } \\
\text { before treatment } \\
\text { (units per month) }\end{array}$} & \multicolumn{2}{|c|}{ Laser or other treatment } & \multirow{2}{*}{$\begin{array}{l}\text { Average blood } \\
\text { requirements } \\
\text { after treatment } \\
\text { (units per month) }\end{array}$} & \multirow[b]{2}{*}{ Duration of remission } \\
\hline & & Initial & Subsequent & & \\
\hline 1 & $\begin{array}{r}8 \\
11 \\
7\end{array}$ & Argon & $\begin{array}{l}\text { Surgery } \\
\text { Surgery }\end{array}$ & $\begin{array}{l}1 \\
1 \cdot 7 \\
0.5\end{array}$ & $\begin{array}{l}2 \mathrm{~m} \\
16 \mathrm{~m} \\
\text { Well at } 40 \mathrm{~m}\end{array}$ \\
\hline 2 & $\begin{array}{l}8 \\
3 \cdot 7 \\
3\end{array}$ & Argon & $\begin{array}{l}\text { Argon } \\
\text { Nd YAG }\end{array}$ & $\begin{array}{l}1 \\
0 \cdot 8 \\
0 \cdot 2\end{array}$ & $\begin{array}{l}12 \mathrm{~m} \\
12 \mathrm{~m} \\
\text { Well at } 18 \mathrm{~m}\end{array}$ \\
\hline 3 & $2 \cdot 7$ & Nd YAG & & Nil & Well at $35 \mathrm{~m}$ \\
\hline 4 & $\begin{array}{l}1 \cdot 3 \\
1 \cdot 3\end{array}$ & Nd YAG & Nd YAG & $\begin{array}{l}\mathrm{Nil} \\
\mathrm{Nil}\end{array}$ & $\begin{array}{l}9 \mathrm{~m} \\
\text { Well at } 6 \mathrm{~m}\end{array}$ \\
\hline 5 & $\begin{array}{l}2 \cdot 7 \\
2 \cdot 7\end{array}$ & Nd YAG & Nd YAG & $\begin{array}{l}\text { Nil } \\
\text { Nil }\end{array}$ & $\begin{array}{l}4 \mathrm{~m} \\
\text { Well at } 10 \mathrm{~m}\end{array}$ \\
\hline 6 & $6 \cdot 7$ & Nd YAG & Surgery* & $\begin{array}{l}0 \cdot 2 \\
\text { Nil }\end{array}$ & $\begin{array}{l}12 \mathrm{~m} \\
\text { Well at } 1 \mathrm{~m}\end{array}$ \\
\hline 7 & 16 & Nd YAG & Surgery & Nil & $\begin{array}{l}\text { Nil. Laser failure } \\
\text { Well at } 4 \mathrm{~m}\end{array}$ \\
\hline 8 & 6 & Nd YAG & & $2 \cdot 7$ & Still under treatment \\
\hline
\end{tabular}

* Rebled three days after Nd YAG laser treatment of residual lesions at routine follow up endoscopy and submitted to surgery at referring hospital.

Table 3 Results for patients with angiodysplasia. Blood transfusion requirements are given in units of $540 \mathrm{ml}$

\begin{tabular}{|c|c|c|c|c|c|c|}
\hline \multirow[b]{2}{*}{ Case No } & \multirow[b]{2}{*}{ Lesion } & \multirow{2}{*}{$\begin{array}{l}\text { Average blood } \\
\text { requirements } \\
\text { before treatment } \\
\text { (units per month) }\end{array}$} & \multicolumn{2}{|c|}{ Laser or other treatment } & \multirow{2}{*}{$\begin{array}{l}\text { Average blood } \\
\text { requirements } \\
\text { after treatment } \\
\text { (units per month) }\end{array}$} & \multirow[b]{2}{*}{ Duration of remission } \\
\hline & & & Initial & Subsequent & & \\
\hline 9 & $\begin{array}{l}\text { Single, } \\
\text { gastric }\end{array}$ & $5 \cdot 3$ & Argon & & Nil & Well at $48 \mathrm{~m}$ \\
\hline 10 & $\begin{array}{l}\text { Single, } \\
\text { duodenum }\end{array}$ & $\begin{array}{r}16 \\
7\end{array}$ & Nd YAG & Nd YAG & $\begin{array}{l}0 \cdot 3 \\
0 \cdot 3\end{array}$ & $\begin{array}{l}8 \mathrm{~m} \\
\text { Died of septicaemia at } \\
9 \mathrm{~m}\end{array}$ \\
\hline 11 & $\begin{array}{l}\text { Single, } \\
\text { gastric }\end{array}$ & $8 \cdot 7$ & Nd YAG & & Nil & Well at $27 \mathrm{~m}$ \\
\hline 12 & $\begin{array}{l}\text { Single, } \\
\text { gastric }\end{array}$ & $2 \cdot 7$ & Nd YAG & & Nil & Well at $8 \mathrm{~m}$ \\
\hline 13 & $\begin{array}{l}\text { Single, } \\
\text { gastric }\end{array}$ & $1 \cdot 8$ & Nd YAG & & Nil & Well at $6 \mathrm{~m}$ \\
\hline 14 & $\begin{array}{l}\text { Multiple, } \\
\text { Roux loop }\end{array}$ & $\begin{array}{r}10 \cdot 3 \\
5 \cdot 2\end{array}$ & Argon & Nd YAG & $\begin{array}{l}\text { Nil } \\
0 \cdot 3\end{array}$ & $\begin{array}{l}14 \mathrm{~m} \\
\text { Well at } 20 \mathrm{~m}\end{array}$ \\
\hline 15 & $\begin{array}{l}\text { Multiple, } \\
\text { gastric }\end{array}$ & $\begin{array}{l}1 \cdot 5 \\
4\end{array}$ & Argon & Nd YAG & $\begin{array}{l}\text { Nil } \\
\text { Nil }\end{array}$ & $\begin{array}{l}8 \mathrm{~m} \\
\text { Died of myocardial } \\
\text { infarction at } 3 \mathrm{~m}\end{array}$ \\
\hline 16 & $\begin{array}{l}\text { Multiple, } \\
\text { gastric }\end{array}$ & 4 & Argon & & Nil & $\begin{array}{l}\text { Died of peritonitis at } \\
18 \mathrm{~m}\end{array}$ \\
\hline 17 & $\begin{array}{l}\text { Multiple, } \\
\text { gastric }\end{array}$ & $8 \cdot 7$ & Nd YAG & $\begin{array}{l}\text { Surgery } \\
\text { Nd YAG }\end{array}$ & Nil & $\begin{array}{l}\text { Rebled during course of } \\
\text { therapy when no laser } \\
\text { operator available. } \\
\text { Rebled within a month } \\
\text { Well at } 10 \mathrm{~m}\end{array}$ \\
\hline 18 & $\begin{array}{l}\text { Diffuse, crosses } \\
\text { pylorus }\end{array}$ & $4 \cdot 2$ & Nd YAG & & $2 \cdot 7$ & Still under treatment \\
\hline
\end{tabular}


Fig. 1 Transfusion requirements and therapeutic procedures for 3 illustrative cases. Case 2 (HHT), case 10 (single angiodysplasia) and case 14 (multiple angiodysplasia). Each vertical line represents the units of blood transfused in one month.

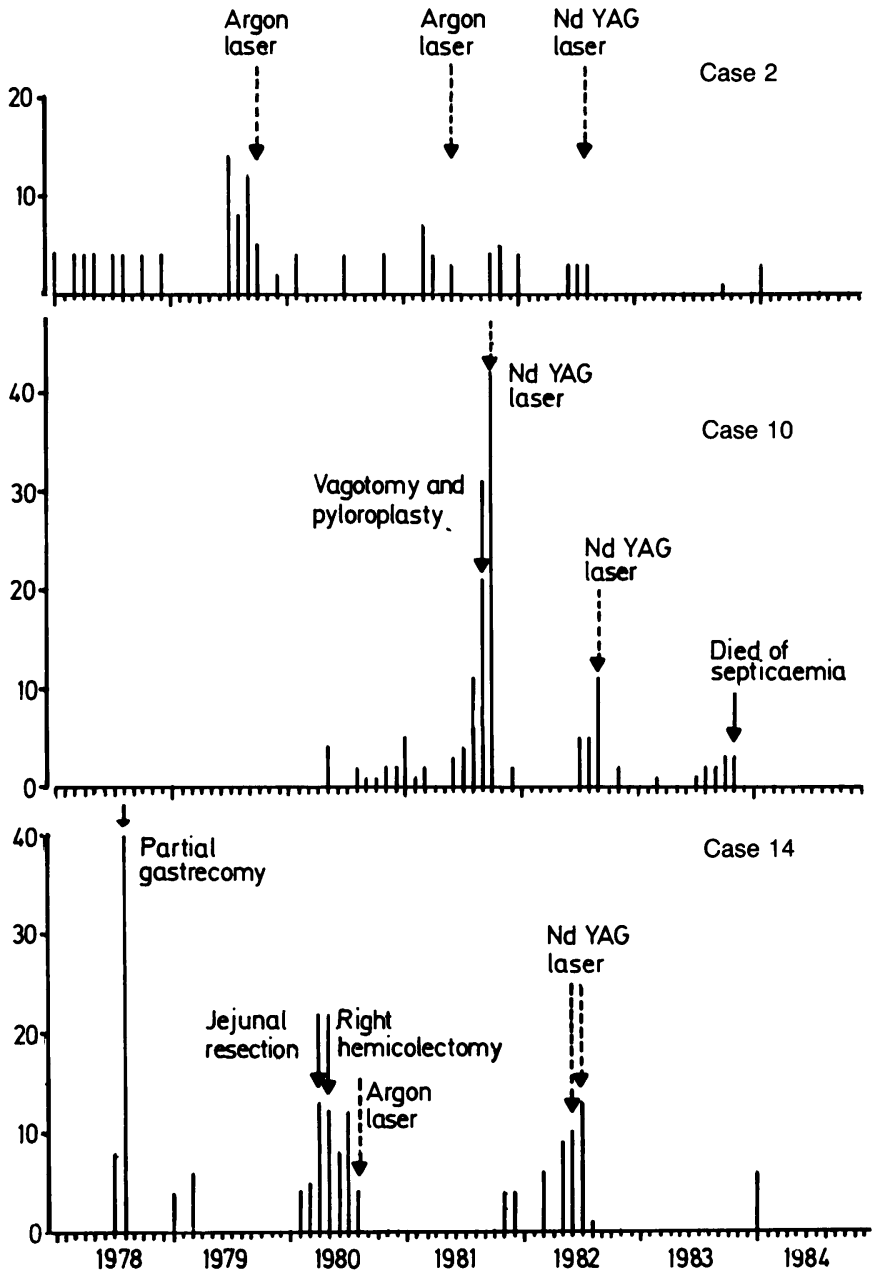

Table 4 Number of laser endoscopies required to complete each course of treatment (this table does not include the three courses of treatment that failed to control haemorrhage)

\begin{tabular}{lll}
\hline & $\begin{array}{l}\text { Initial Course } \\
\text { mean (range) }\end{array}$ & $\begin{array}{l}\text { Subsequent Course } \\
\text { mean (range) }\end{array}$ \\
\hline HHT & $5(2-11)$ & $2(1-2)$ \\
$\begin{array}{l}\text { Single } \\
\text { angiodysplasia } \\
\text { Multiple }\end{array}$ & $3(1-4)$ & $2(1$ case only) \\
\hline
\end{tabular}

Two cases still under treatment:

Case 8 -six endoscopies so far. Multiple large lesions in stomach still to treat.

Case 18 - ten endoscopies so far. Doubt if full extent of lesion has been identified or treated. bleeding point in one of the treated lesions.

Detailed studies were possible on two of the three specimens available following resection of gastric lesions previously treated endoscopically. Figure 2 shows an angiogram of the resected stomach in case 1 , which reveals discrete areas of vascular ectasia. Only the argon laser was used in this case. A section through a treated lesion is shown in Fig. 3. Figure 4 illustrates a section taken adjacent to a treated telangiectasia. Only a small sleeve resection was made in case 7 and we were unable to identify the precise bleeding point in the specimen. Figure 5, however, shows a section through the treated area (only the Nd YAG laser was used in this case). Quantitative measurements showed the zone of 
Table 5 Outcome of each course of laser therapy (1-3 courses per patient)

\begin{tabular}{llllll}
\hline & $\begin{array}{l}\text { Definite } \\
\text { benefit }\end{array}$ & $\begin{array}{l}\text { Probable } \\
\text { benefit }\end{array}$ & Failure & $\begin{array}{l}\text { Courses } \\
\text { (total no) }\end{array}$ & $\begin{array}{l}\text { Patients } \\
\text { (no) }\end{array}$ \\
\hline HHT & 6 & $5^{*}$ & $3+$ & 14 & 8 \\
Single angiodysplasia & 6 & -7 & 6 & 5 & 4 \\
Multiple angiodysplasia & 3 & 3 & $1 \ddagger$ & 7 & 4 \\
\hline
\end{tabular}

* One course of treatment not yet complete. $\dagger$ Includes one patient who rebled at referring hospital four days after laser treatment. $\ddagger$ Laser operator unavailable at time of bleed.

Definite benefit: reduction in average monthly transfusion requirements for six months after treatment to less than $10 \%$ of those in three months before treatment and at least eight units total transfusion requirement before treatment.

Probable benefit: (a) reduction in average monthly transfusion requirements for three months after treatment to less than $50 \%$ of those in three months before treatment, or (b) no transfusions after treatment, but less than eight units required before treatment.

Failure: laser unable to control blood loss, urgent surgery required.

coagulative necrosis to extend $0.5 \mathrm{~mm}$ below the surface of the resected stomach after argon laser treatment and $2.1 \mathrm{~mm}$ after the Nd YAG. The zone of inflammation and fibrosis extended $1.0 \mathrm{~mm}$ below the surface for the Argon laser and $3.4 \mathrm{~mm}$ for the Nd YAG.

\section{Discussion}

The primary defect in these vascular lesions is unknown, but is probably one of connective tissue in small veins. Both haemorrhagic telangiectasia and angiodysplasias consist of collections of delicate vessels lined by a single layer of endothelial cells and supported by a fine layer of connective tissue with no elastic lamina. Tortuosity of the vessels within each lesion is common. In the gastrointestinal tract they occur predominantly in the submucosa, though may involve the mucosa or the external muscle layer. ${ }^{48}$ The natural history of haemorrhage from lesions such as these is poorly documented. Many are entirely asymptomatic. Boley showed submucosal lesions of varying severity in otherwise normal regions of colons resected for carcinoma and suggested that these might evolve into typical angiodysplasias that could bleed. ${ }^{4}$ Theodore identified 40 patients with angiodysplasias (proven on biopsy) in the stomach or duodenum in 3300 upper GI endoscopies, but only five bled. ${ }^{19}$
The factors precipitating episodes of haemorrhage are often unknown. Local trauma from food passing may play a part, although increased pressure in the pathological vessels is probably more important. The association between haemorrhage from angiodysplasia and valvular heart disease may be due to increased venous pressure. One of our patients (case 17) was noted to be in mild congestive cardiac failure the day before an episode of bleeding started and there has been an anecdotal report of bleeds from an angiodysplasia of the caecum ceasing after surgery for aortic stenosis (personal communication). In general, most reports suggest that once bleeding does occur, it becomes more frequent and more severe with advancing age ${ }^{35}$ but the intermittent occurrence of bleeding episodes makes it difficult to assess the effect of therapeutic manoeuvres unless a long period of follow up is possible. Spontaneous cessation of haemorrhage for several years may occur. Case 3 in this report first required transfusion in 1950, averaged 4 units per year until 1960 , but then needed none for five years. After that, she again averaged 4 units per year until the accelerated blood loss developed which led to her referral to University College Hospital.

Treatment of the underlying condition has proved difficult. No satisfactory pharmacological agent has been identified to reduce GI blood loss (although oestrogens do reduce loss from epistaxis in patients

Table 6 Current situation of treated patients

\begin{tabular}{|c|c|c|c|c|}
\hline & $\begin{array}{l}\text { No major blood loss after laser } \\
\text { treatment alone (died since laser } \\
\text { therapy of unrelated causes) }\end{array}$ & $\begin{array}{l}\text { Well after surgery for } \\
\text { haemorrhage }\end{array}$ & $\begin{array}{l}\text { Still under } \\
\text { treatment }\end{array}$ & Total \\
\hline HHT & $4(0)$ & $3\left(1^{*}\right)$ & 1 & 8 \\
\hline Single angiodysplasia & $5(1)$ & - & - & 5 \\
\hline Multiple angiodysplasia & $3(2)$ & $1^{*}$ & - & 4 \\
\hline Diffuse angiodysplasia & - & - & 1 & 1 \\
\hline
\end{tabular}

${ }^{*}$ These two patients were only submitted to surgery as laser treatment was not available at the time of a severe bleed. 


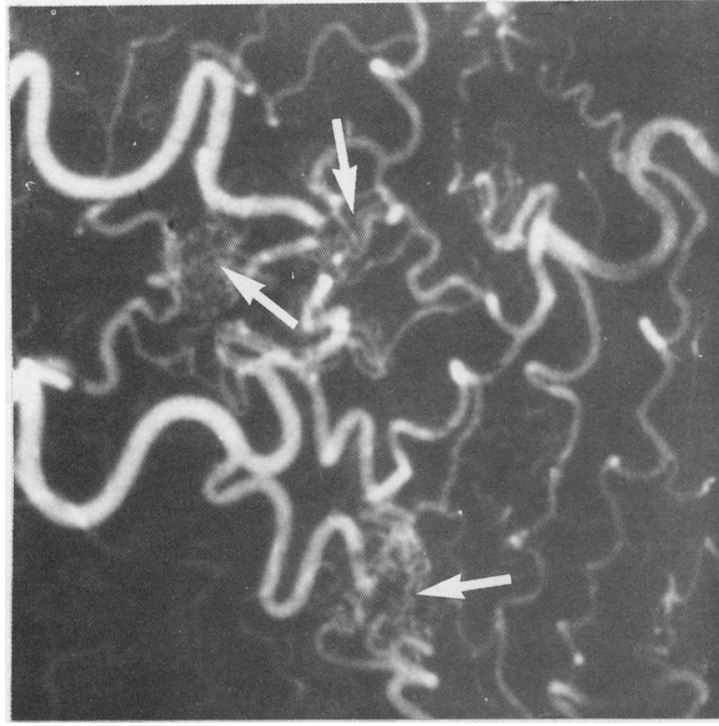

Fig. 2 Angiogram of resected stomach in case 1. Arrows indicate the main areas of vascular ectasia, each fed by several small arterioles. $(\times 15)$. with haemorrhagic telangiectasia). ${ }^{10}$ Single angiodysplasias can be treated successfully by surgery if their location can be identified precisely by angiography or endoscopy. ${ }^{9}{ }^{20}$ Likewise, the five cases with single upper gastrointestinal tract lesions that we have treated endoscopically have done well, only one requiring a second course of treatment, which was successful. The distribution of multiple lesions often makes complete resection impossible, particularly as new lesions tend to form later in other areas. ${ }^{3}$ Two of our four cases that came to surgery bled again later. Case 1 required a revision gastrectomy 16 months after the first operation. Case 17 bled again from the gastric remnant within a month of his subtotal gastrectomy, but was then successfully treated with the Nd YAG laser. In retrospect, both these patients might not have rebled if their initial operation had been a total gastrectomy, but even now, both are potentially at risk from haemorrhage from other parts of the GI tract. In many cases, the physician is also faced with the difficult task of deciding whether a particular lesion is a significant source of blood loss. In four of our patients (cases 7,11,14, and 18) lesions were positively identified by angiography or endoscopy in

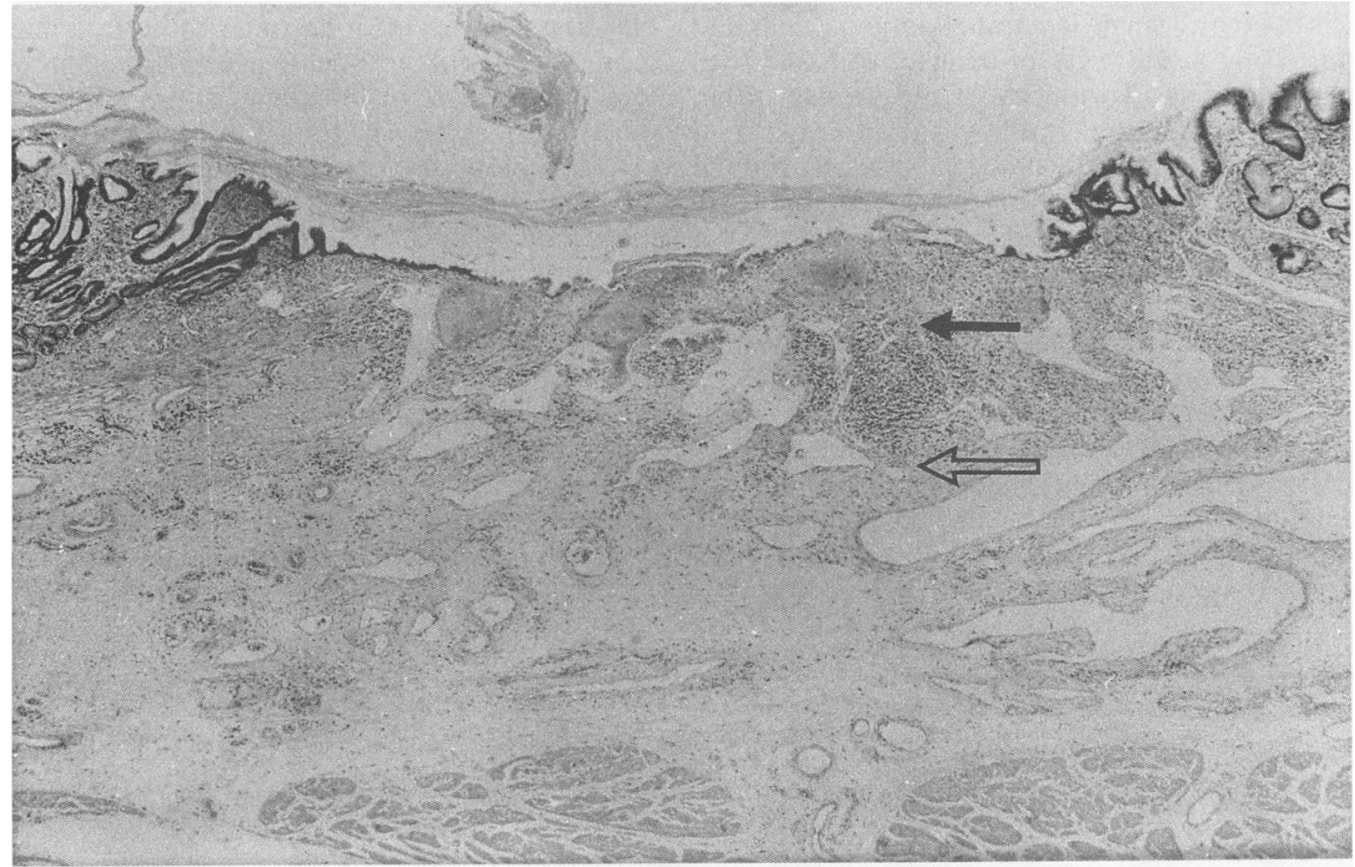

Fig. 3 Section of telangiectasia in case 1, previously treated with the Argon laser. Closed arrow: approximate limit of zone of coagulative necrosis. Open arrow: approximate limit of zone of inflammation and fibrosis $(H \& E \times 35$ original magnification). 


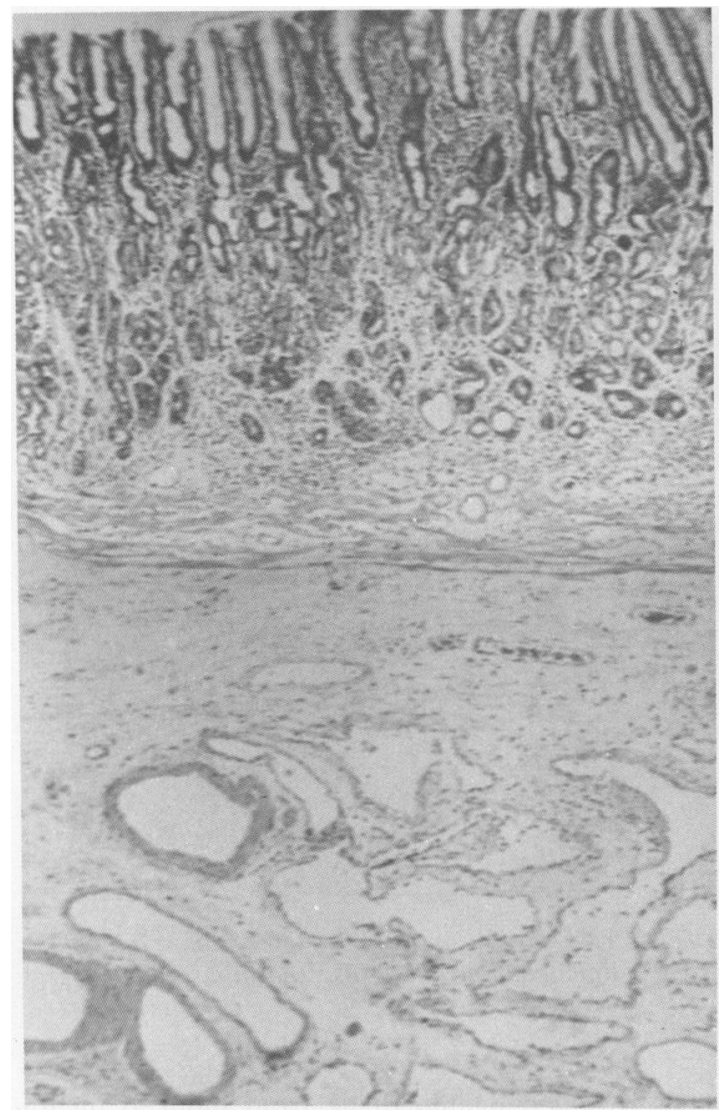

Fig. 4 Section adjacent to a treated telangiectasia (case 1). Normal mucosa overlies the extensive vascular ectasia in the submucosa ( $H \& E \times 350$ original magnification).

the small or large bowel, but resection of the affected areas failed to stop the bleeding. Haemorrhage from single lesions is virtually unknown in haemorrhagic telangiectasia (although case 7 bled predominantly from one site) and about half of patients with angiodysplasia have multiple lesions. ${ }^{1}$ Thus, an endoscopic technique must be the most promising approach, particularly as the vast majority of lesions which bleed are located within reach of the gastroduodenoscope or colonoscope.

The first and most extensively used technique has been diathermy. Rogers reported control of haemorrhage in five cases of caecal 'haemangiomas' without complicaiton ${ }^{11}$ but a more detailed analysis by Weaver ${ }^{5}$ reveals several problems. After treatment designed to ablate the vascular lesions, deep ulcerations developed in most areas of coagulation and in several instances, there was delayed bleeding from these iatrogenic ulcers. In those cases, it was difficult to decide whether the patient was bleeding from the iatrogenic ulcer or from the original vascular malformation. No perforations occurred, however, and three out of four patients benefited (one requiring multiple coagulations). Jensen has had encouraging results with the heater probe and bicap probe in 26 patients. ${ }^{13}$ Another technique that has been reported recently is endoscopic sclerotherapy. ${ }^{12}$ One half to 1 millilitre of sodium morrhuate was injected submucosally, and this stopped all bleeding from three patients with haemorrhagic telangiectasia (follow up six to 12 months). This approach is simple and inexpensive, but needs fuller assessment.

Problems of electrode tissue adherence and difficulty predicting the extent of tissue damage produced by diathermy led to a search for alternative no-touch techniques. The argon and Nd YAG lasers seemed the most promising of these. The laser energy is delivered via a flexible fibre passed through the biopsy channel of the endoscope and held above the target area without touching it. Experimental studies show that the extent of damage is more predictable than with diathermy and depends on the energy dissipated. ${ }^{17} 2122$ Encouraging results with the argon laser have been reported. Waitman et al had complete cessation of bleeding in $66 \%$ of 50 patients with six months to four years follow up. ${ }^{16}$ In 30 patients, Jensen et al showed a significant reduction in emergency admissions for haemorrhage, total transfusions and surgery. ${ }^{13}$ Our own early results with this laser were promising. When our first case required an emergency gastrectomy and we had the opportunity to study the effects of our treatment on the resected specimen, however, it became apparent that the argon laser was only treating the tip of the iceberg. Even though a small ulcer had been deliberately created at endoscopy, the extensive submucosal vascular malformation had hardly been touched, either immediately below the treated area or more laterally under normal mucosa (Figs 3 and 4). This would make it more likely that the bleeding could recur later if further vascular ectasias formed in the mucosa which could link the persisting submucosal vascular lake with the lumen of the intestine. It was for this reason that we changed to the Nd YAG laser which can coagulate through a greater depth of tissue. Case 7 gave us an opportunity to study the effects after treatment with the Nd YAG laser (Fig. 5) and from the measurements on these sections (given above) it is apparent that the zone of inflammation and fibrosis is three to four times thicker than with the argon laser. This zone represents the region where one can hope to ablate the vascular ectasia and replace it with fibrosis and as its thickness is 


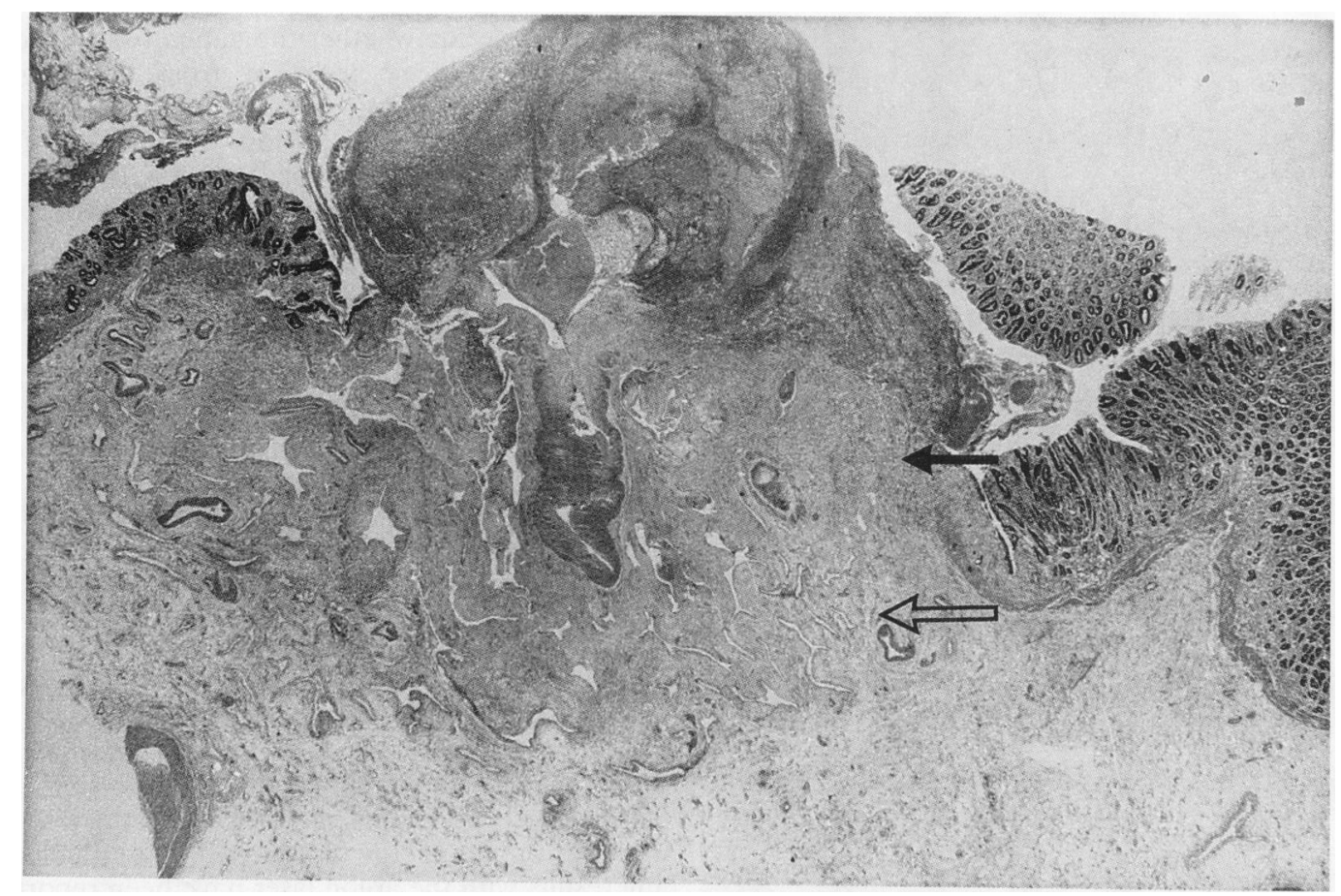

Fig. 5 Section of telangiectasia in case 7 previously treated with the Nd YAG laser. Closed arrow: approximate limit of zone of coagulative necrosis. Open arrow: approximate limit of zone of inflammation and fibrosis (haemotoxylin and tartrazine $\times 23$ original magnification).

only adequate to cover the full thickness of the submucosa following Nd YAG laser treatment, this laser would seem the more suitable for treating these lesions.

Fortunately, the lesions of both haemorrhagic telangiectasia (as in Fig. 2) and angiodysplasias ${ }^{9}$ are usually well localised, so Nd YAG laser treatment should be able to ablate them without loss of large areas of functioning gastric mucosa and submucosa. Endoscopically, it is impossible to know the precise extent of submucosal spread beyond the visible mucosal lesion. High quality microangiography may help to delineate the extent of single large lesions, but it is difficult to correlate with endoscopic findings in the presence of multiple lesions. Our current practice is to treat the area of the mucosal lesion and a band around its edge knowing that the Nd YAG laser light is scattered up to $5 \mathrm{~mm}$ in all directions within the tissue and hope that this is sufficient to destroy the most important areas of submucosal ectasia. Johnson achieved reduction or complete cessation of bleeding in 19 of 22 patients with the Nd YAG laser, although reported delayed massive haemorrhage seven to 16 days after treatment in three.$^{14}$ Examination of his surgical speci- mens revealed haemorrhage from induced ulceration at the treatment site comparable to Weaver's results after diathermy. ${ }^{5}$ This ulceration was more than one might wish, but the energy used was not stated, and may have been particularly high in these cases. We also had three cases in which delayed haemorrhage may have been related to Nd YAG laser treatment one of which was severe enough to warrant surgery. Experimental studies show that the tissue damage in gastric mucosa after single shots from a Nd YAG laser is maximum seven days after treatment ${ }^{23}$ (in contrast with the argon laser where the maximum effect is apparent at once).${ }^{17}$ Around each treated spot there is a range of effects, as shown in Fig. 5, the extent of each depending on the power and exposure time used. At the centre, necrosed tissue sloughs. Adjacent areas mount an inflammatory response which leads to fibrosis and beyond this only oedema is seen. Thus, if the edge of the zone of necrosis occurs within the area of vascular ectasia, this might lead to delayed haemorrhage. Ideal laser treatment parameters would maximise fibrosis and minimise necrosis associated with sloughing. No data are available to determine these optimum values, but it is likely that lower 
powers with longer exposure times are most appropriate (in contrast with the high power, short exposure times found to be most effective in treating haemorrhage from peptic ulcers). ${ }^{22}$ We limited the total energy on any one area to minimise the risk of perforation, but it is difficult to relate the energy dissipated to the risk of delayed haemorrhage there was no correlation in this series. The risk of delayed haemorrhage may be reduced by starting treatment at the edge of the lesion rather than the centre, so the feeding vessels at the sides are occluded first, and this is our current practice.

The large variations in transfusion requirements between patients, and the small total numbers in this series, make it difficult to compare the clinical results with the two lasers. Two patients had treatment from both. Case 14 had comparable results with each, Case 2 has had a considerably better and longer remission after the Nd YAG laser than after either of her argon courses. Cases 3 and 11 had particularly good results after Nd YAG therapy. Neither has required transfusion for over two years, after previous total transfusions of 129 and 52 units respectively. On histological grounds, the Nd YAG should be superior as it can ablate the submucosal lesions without risk of perforation and it is our clinical impression that this is the case. There is a small risk, however, that this laser can cause delayed haemorrhage which was not seen with the argon laser. This may be avoidable by using alternative laser settings.

On current evidence, carefully controlled endoscopic thermal ablation of these lesions seems the most appropriate approach to the long term management of these patients and the $\mathrm{Nd}$ YAG laser appears superior to diathermy and the argon laser. Further long term studies are needed, however, to compare laser therapy with the various alternative techniques available.

We should like to thank the following for referring these cases from all parts of England and Wales and for help in documenting precise transfusion requirements and for permission to report these results: Drs C H Burns Cox, J R Dowdle, I Gilbert, P L Golding, N F Jones, E C B Keat, R Lendrum, J N Mickerson, A Pearson, N Peters, D Rampton, Mr J Spencer, Drs R Taylor, D S Tunstall-Pedoe, M J Williams and A J Wing. We should also like to thank Miss S Williams, Mr D Ellis and Mr P Luther for preparing the illustrations, Miss $J$ Forster for typing the manuscript and Sister Ramu and the staff of the Endoscopy Unit for their continual help and support. This work was carried out with the support of a grant from the DHSS.

\section{References}

1 Clawse RE, Costigan DJ, Mills BA, Zuckerman GR. Angiodysplasia of the stomach and duodenum: a review of 30 cases. Gastrointest Endosc 1982; 28: 129.

2 Jensen DM, Machicado GA, Tapia JI et al. Argon laser photocoagulation of bleeding colonic lesions. Proceedings of Laser Tokyo '81: 1981; 20-4.

3 Smith CR, Bartholomew LG, Cain JC. Hereditary haemorrhagic telangiectasia and gastrointestinal haemorrhage. Gastroenterology 1963; 44: 1-6.

4 Boley SJ, Sammartano R, Adams A et al. On the nature and etiology of vascular ectasias of the colon. Gastroenterology 1977; 72: 650-60.

5 Weaver GA, Alpern HD, Davis JS et al. Gastrointestinal angiodysplasia associated with aortic valve disease: part of a spectrum of angiodysplasia of the gut. Gastroenterology 1979; 77: 1-11.

6 Cunningham JT. Gastric telangiectasias in chronic hemodialysis patients: a report of six cases. Gastroenterology 1981; 81: 1131-3.

7 Jahnke V. Ultrastructure of hereditary telangiectasia. Arch Otolaryngol 1970; 91: 262-5.

8 Bird RM, Jaques WE. Vascular lesion of hereditary haemorrhagic telangiectasia. $N$ Engl J Med 1959; 260: 597-9.

9 Miller KD, Tutton RH, Bell KA, Simon BK. Angiodysplasia of the colon. Radiology 1979; 132: 309-13.

10 Harrison DFN. Use of estrogen in treatment of familial haemorrhagic telangiectasia. Laryngoscope 1982; 92: 314-20.

11 Rogers BHG, Adler F. Haemangioma of the cecum. Colonoscopic diagnosis and therapy. Gastroenterology 1976; 71: 1079-82.

12 Young W, Gibbert V, Feinstat T, Trudeau W. The recurrent upper gastrointestinal bleeding in hereditary hemorrhagic telangiectasia (Osler's Disease) successfully treated by endoscopic sclerotherapy. Gastrointest Endosc 1982; 28: 148.

13 Jensen DM, Machicado GA, Silpa ML. Treatment of GI angioma with argon laser, heater probe or bipolar electrocoagulation. Gastrointest Endosc 1984; 30: 134.

14 Johnson JH. Complications following endoscopic laser therapy. Gastrointest Endosc 1982; 28: 135.

15 Bowers JH, Dixon JA. Argon laser photocoagulation of vascular malformations in the GI tract. Short term results. Gastrointest Endosc 1982, 28: 126.

16 Waitman AM, Grant DZ, Chateau F. Argon laser photocoagulation treatment of patients with acute and chronic bleeding secondary to telangiectasia. Gastrointest Endosc 1982; 28: 153.

17 Bown SG, Salmon PR, Kelly DF et al. Argon laser photocoagulation in the dog stomach. Gut 1979; 20: 680-7.

18 Dixon JA, Berenson MM, McCloskey DW. Nd YAG laser treatment of experimental canine gastric bleeding. Gastroenterology 1979; 77: 647-51.

19 Theodore C, Leymarious J, Molas G, Paolaggi JA. Gastroduodenal angiodysplasias: endoscopic study of 40 cases. Scand J Gastroenterol 1982; 17: suppl 78: 4.

20 Wolff WI, Grossman MB, Shinya H. Angiodysplasia of 
the colon: diagnosis and treatment. Gastroenterology 1977; 72: 329-33.

21 Protell RL, Gilbert DA, Jensen DM et al. Computer assisted electrocoagulation bipolar $v s$ monopolar in the treatment of experimental gastric bleeding. Gastroenterology 1981; 80: 451-5.
22 Bown SG, Salmon PR, Storey DW et al. Nd YAG laser photocoagulation in the dog stomach. Gut 1980; 21: 818-25.

23 Kelly DF, Bown SG, Calder BM et al. Histological changes following Nd YAG laser photocoagulation of canine gastric mucosa. Gut 1983; 24: 914-20. 